\title{
Penggunaan serotonin dalam formulasi hormon pregnant mare serum gonadotropin dan antidopamin untuk menginduksi perkembangan gonad ikan ringau, Datnioides microlepis Bleeker, 1854
}

[Serotonin application in pregnant mare serum gonadotropin hormone and dopamin antagonist formulation to induce gonadal development of Indonesian tigerfish (Datnioides microlepis Bleeker, 1854)]

\author{
Bastiar $^{1}$, Agus Oman Sudrajat ${ }^{2}$, Melta Rini Fahmi ${ }^{1}$ \\ ${ }^{1}$ Balai Penelitian dan Pengembangan Budidaya Ikan Hias \\ Jl. Perikanan No. 13 Pancoran Mas, Depok 16436 \\ ${ }^{2}$ Departemen Budidaya Perairan, Fakultas Perikanan dan Ilmu Kelautan, IPB \\ Jalan Agatis 1, kampus IPB Dramaga 16680 \\ Diterima: 12 Mei 2017; Disetujui: 17 Januari 2017
}

\begin{abstract}
Abstrak
Penelitian ini bertujuan untuk menganalisis pengaruh penggunaan serotonin (5-hydroxytryptamine atau 5-HT) dalam formulasi hormon Pregnant Mare Serum Gonadotropin (PMSG) dan antidopamin (AD) terhadap perkembangan gonad ikan ringau. Penelitian ini menggunakan rancangan acak lengkap dengan lima perlakuan (dosis. $\mathrm{kg}^{-1}$ bobot tubuh ikan): (P1) $1 \mathrm{ml} \mathrm{NaCl}$ 0,9\% (kontrol); (P2) 20 IU PMSG+10 mg AD; (P3) 20 IU PMSG+10 mg AD+0,2 mg 5-HT; (P4) 20 IU PMSG+10 mg AD+2 mg 5-HT; dan (P5) 20 IU PMSG+10 mg AD+4 mg 5-HT. Setiap perlakuan diujikan pada lima ekor ikan sebagai ulangan individu. Penyuntikan hormon dilakukan setiap 10 hari dengan lama penelitian 60 hari. Hormon disuntikkan secara intramuskular pada bagian bawah sirip punggung ikan uji. Ikan yang digunakan merupakan hasil tangkapan alam dengan ukuran panjang total 17,5-33,0 cm dan bobot tubuh 118-926 g. Selama penelitian, ikan uji diberi pakan berupa udang dan ikan-ikan kecil (hidup) dua kali sehari secara satiasi. Parameter yang diamati adalah indeks kematangan gonad, indeks hepatosomatik, konsentrasi estradiol-17 $\beta$ plasma dan tingkat kematangan gonad berdasarkan morfologi dan histologi gonad. Hasil penelitian menunjukkan penggunaan 2 mg 5-HT dalam 20 IU PMSG dan $10 \mathrm{mg}$ AD (perlakuan P4) menghasilkan perkembangan gonad yang lebih baik dibandingkan perlakuan lainnya. Nilai indeks kematangan gonad, indeks hepatosomatik, dan konsentrasi E2 plasma tertinggi diperoleh pada perlakuan P4

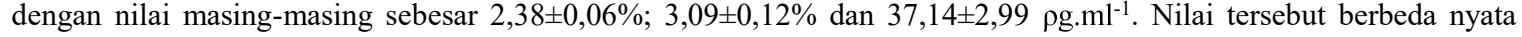
$\mathrm{p}<0.05$ ) dengan perlakuan lainnya. Perlakuan P4 meningkatkan konsentrasi E2 plasma dua kali lebih besar dibandingkan sebelum penyuntikan serta menghasilkan perkembangan gonad yang mencapai tingkat kematangan gonad tahap III.
\end{abstract}

Kata penting: ikan ringau, perkembangan gonad, PMSG, serotonin

\begin{abstract}
The objective of study was to analyze the effect of serotonin (5-HT) in the formulation of hormones Pregnant Mare Serum Gonadotropin (PMSG) and dopamin antagonist (AD) hormones to gonad development of tigerfish. This study used completely randomized design (CRD) with five treatments of hormone namely: (P1) $1 \mathrm{ml}$ of $0.9 \% \mathrm{NaCl}$ (control); (P2) 20 IU PMSG+10 mg AD; (P3) 20 IU PMSG AD+10 mg+0.2 mg 5-HT; (P4) 20 IU PMSG+10 mg AD+2 mg 5HT; and (P5) $20 \mathrm{IU}$ PMSG+10 mg AD+4 mg 5-HT. Each treatment was tested on five fish as individual replications. Hormone injected intramuscularly at the lower part of the dorsal fin of fish every 10 days. The fish were reared for 60 days. Fish that were used at this study were originate from natural catches as much as 25 fishes with $17.5-33.0 \mathrm{~cm}$ of total length and 118-926 g of body weight. During the study, fish fed using shrimp and small fish (live) twice daily at satiation. Measured parameters were gonadosomatic index (GSI), hepatosomatic index (HSI), 17 $\beta$-estradiol (E2) plasma concentration and gonad maturity level based on morphology and histology examination. The results showed that the use of $2 \mathrm{mg}$ of 5-HT are added to 20 IU PMSG and $10 \mathrm{mg} \mathrm{AD} \mathrm{(treatment} \mathrm{P4)} \mathrm{has} \mathrm{stimulated} \mathrm{the} \mathrm{fish} \mathrm{to} \mathrm{had} \mathrm{the} \mathrm{highest}$ GSI $(2.38 \pm 0.06 \%)$ and HSI $(3,09 \pm 0,12 \%)$ which was significantly different to other treatment. The treatment (P4) could increase the E2 plasma concentration $\left(37.14 \pm 2.99 \rho \mathrm{gg} . \mathrm{ml}^{-1}\right)$ two fold compared with the concentration before injection and stimulated the gonadal development to stage III.
\end{abstract}

Keywords: Indonesian tigerfish, gonadal development, PMSG, serotonin

$\triangle$ Penulis korespondensi

Alamat surel: bastiarnurdin@gmail.com 


\section{Pendahuluan}

Ikan ringau atau Indonesian tiger fish (Datnioides microlepis) merupakan salah satu spesies ikan hias air tawar dari famili Datnioididae yang hidup di perairan sungai dan danau di daerah Sumatera dan Kalimantan (Kottelat et al. 1993). Ikan ringau sangat potensial untuk dikembangkan karena termasuk salah satu ikan hias komoditas ekspor yang memiliki harga dan permintaan yang relatif cukup tinggi namun pemenuhannya masih mengandalkan hasil tangkapan dari alam. Tingginya permintaan pasar menyebabkan aktifitas penangkapannya semakin tinggi pada berbagai ukuran sehingga mengancam kelestariannya. Disamping itu kerusakan habitat akibat perubahan fungsi lahan menjadi area pertambangan, perkebunan, dan permukiman menyebabkan terjadinya penurunan populasinya bahkan menjurus kepada kepunahan. Oleh karena itu, kegiatan budi daya menjadi salah satu upaya konservasi ex situ untuk mencegah kepunahan, mengurangi tekanan populasi di alam, dan untuk memenuhi kebutuhan pasar ikan hias.

Keberhasilan pemijahan ikan ringau dalam lingkungan budi daya sangat bergantung pada ketersediaan induk matang gonad, namun pematangan gonad ikan ringau dalam wadah budi daya masih mengalami berbagai permasalahan. Upaya pematangan gonad ikan ringau dalam lingkungan terkontrol telah dilakukan baik melalui pendekatan lingkungan dengan merekayasa wadah pemeliharaan (Sholichah et al. 2010), pemeliharaan berdasarkan kelompok ukuran yang sama (Rohmy et al. 2012), pemeliharaan dalam media air bersalinitas rendah (Rohmy et al. 2014), maupun melalui pendekatan pakan dengan pemberian kombinasi berbagai jenis pakan alami (Rohmy et al. 2011) belum mampu merangsang perkembangan gonadnya yang dapat dipijahkan baik secara alami maupun buatan. Permasalahan lain yang dihadapi dalam upaya pemijahan ikan ringau adalah keterbatasan ukuran induk serta kurangnya informasi tentang daur reproduksinya.

Kemampuan ikan ringau untuk memijah di alam dipengaruhi oleh berbagai faktor lingkungan diantaranya suhu perairan, fotoperiode, curah hujan, substrat, $\mathrm{pH}$, alkalinitas, arus sungai, dan kedalaman perairan (Mananos et al. 2009, Podhorec \& Kouril 2009). Dalam wadah budi daya, beberapa faktor lingkungan yang memengaruhi fungsi reproduksi tidak tersedia sehingga ikan tidak dapat melangsungkan aktifitas reproduksinya dengan baik (Keys \& Crocos 2006, Mylonas et al. 2010, Lorenzen et al. 2012). Beberapa faktor lingkungan yang berperan dalam reproduksi seperti suhu, fotoperiode, salinitas, dan substrat pemijahan dapat dimanipulasi, namun ada juga faktor lingkungan yang sulit dimanipulasi seperti alur ruaya pemijahan, kedalaman, dan tekanan air sehingga memengaruhi stimulasi reproduksi ikan (Gallego et al. 2012). Oleh karena itu, penggunaan hormon eksogen merupakan salah satu cara yang efektif untuk merangsang pematangan gonad pada ikan (Mylonas et al. 2010). Salah satu hormon yang dapat diterapkan dalam pematangan gonad ikan adalah Pregnant Mare Serum Gonadotropin (PMSG) (Nagahama et al. 1991, Gallego et al. 2012).

Hormon PMSG merupakan glikoprotein kompleks yang diperoleh dari serum kuda hamil yang memiliki sifat aktivitas biologis ganda sebagai hormon gonadotropin $(\mathrm{GtH})$, yaitu berefek Follicle Stimulating Hormone (FSH) yang berperan pada proses perkembangan gonad (vitelogenesis) dan Luteinizing Hormone (LH) yang berperan pada proses pematangan akhir (Gallego et al. 2012). PMSG merangsang terjadinya lonjakan kadar GtH sehingga mempercepat terjadinya per- 
kembangan gonad dan ovulasi (Bolamba et al. 1992). Sintesis dan sekresi hormon gonadotropin (GtH) dari kelenjar hipofisis dipengaruhi oleh neurotransmitter yang diproduksi di hipotalamus dan daerah preoptik otak ikan, yaitu dopamin. Dopamin menghambat sekresi Gonadotropin Releasing Hormon (GnRH) dari hipotalamus (Kreke \& Dietrich 2008). Kerja dopamin dapat dihambat dengan pemberian antidopamin (AD) sehingga sekresi gonadotropin akan meningkat. Neurotransmitter lain yang berperan dalam proses perkembangan gonad adalah serotonin atau 5-hydroxytryptamine (5-HT) (Iwamatsu et al. 1992, Khan \& Thomas 1992, Iwamatsu et al. 1993, Cerda et al.1998a). Serotonin berperan memodulasi fungsi reproduksi ikan melalui beberapa jalur termasuk melalui area preoptichipotalamus, hipofisis maupun langsung bekerja pada gonad, serta bertindak dalam memberi pengaruh stimulasi pada sel gonadotropin dan menghambat sekresi dopamin sehingga meningkatkan kadar hormon gonadotropin (Somoza et al. 1988, Prazad et al. 2015). Penyuntikan hormon PMSG dan AD yang dikombinasikan dengan 5-HT diharapkan dapat memicu proses vitellogenesis dan maturasi gonad ikan ringau. Penelitian ini bertujuan untuk menganalisis pengaruh penggunaan serotonin $(5-\mathrm{HT})$ dalam formulasi hormon Pregnant Mare Serum Gonadotropin (PMSG) dan antidopamin (AD) terhadap perkembangan gonad ikan ringau.

\section{Bahan dan metode}

\section{Waktu dan tempat penelitian}

Penelitian dilaksanakan bulan Mei-Agustus 2014 di Laboratorium Reproduksi, Balai Penelitian dan Pengembangan Budidaya Ikan Hias (BPPBIH) Depok. Analisis konsentrasi hormon estradiol-17 $\beta$ dilakukan di Laboratorium Biologi, BPPBIH dan analisis histologi gonad dilakukan di Laboratorium Biologi Perkembangan dan Reproduksi, Fakultas MIPA Universitas Indonesia.

\section{Bahan penelitian}

Bahan penelitian yang digunakan yaitu ikan ringau (Datniodes microlepis) berukuran panjang total 17,5-33,0 cm dan bobot tubuh 118 926 g yang diperoleh dari pengumpul dan merupakan hasil tangkapan alam di daerah Palembang (Sumatera Selatan), hormon Pregnant Mare Serum Gonadotropin (PMSG) dan antidopamin (AD) serta serotonin atau 5-hydroxytryptamine (5-HT) produksi Sigma. Sebelum ditebar, masing-masing ikan uji diberi penanda (microchip implant) yang dipasangkan di bawah permukaan kulit bagian punggung ikan menggunakan jarum tagging.

\section{Rancangan percobaan}

Penelitian ini menggunakan rancangan acak lengkap dengan lima perlakuan dan lima ulangan individu ikan. Perlakuan yang diujikan adalah penambahan serotonin (5-HT) dengan dosis berbeda yaitu $0 ; 0,2 ; 2$; dan $4 \mathrm{mg}$ ke dalam formulasi hormon $20 \mathrm{IU}$ PMSG dan $10 \mathrm{mg}$ AD (PMSG-AD). Kombinasi hormon perlakuan dibuat dalam bentuk larutan dan dosis penyuntikan sebesar $1 \mathrm{ml} . \mathrm{kg}^{-1}$ bobot tubuh ikan uji. Perlakuan uji terdiri atas: (P1) larutan fisiologis $(\mathrm{NaCl}$ 0,9\%) sebagai kontrol, (P2) PMSG-AD, (P3) PMSG-AD+0,2 mg 5-HT, (P4) PMSG-AD+2 mg 5-HT, dan (P5) PMSG-AD+4 mg 5-HT.

\section{Pemeliharaan ikan uji dan penyuntikan hormon}

Ikan dipelihara dalam bak semen berukuran $200 \times 150 \times 100 \mathrm{~cm}^{3}$ dengan ketinggian air 85 $\mathrm{cm}$ dilengkapi dengan sistem sirkulasi. Selama pemeliharaan, ikan uji diberi pakan berupa udang dan ikan kecil secara satiasi. Kondisi air media pemeliharaan selama penelitian relatif stabil de- 
ngan suhu berkisar $26,3-29,9^{\circ} \mathrm{C}, \mathrm{pH}$ air berkisar 5,4-6,5; dan oksigen terlarut 7,41-7,53 mg. $\mathrm{L}^{-1}$.

Penyuntikan dilakukan setiap 10 hari dengan lama pemeliharaan 60 hari. Sebelum penyuntikan, ikan terlebih dahulu dibius menggunakan ethylene glycol monophenyl ether dengan dosis $0,3 \mathrm{ml} . \mathrm{L}^{-1}$ air. Kemudian dilakukan penimbangan untuk menentukan jumlah hormon yang diberikan. Penyuntikan hormon dilakukan secara intramuskular pada bagian bawah sirip punggung.

\section{Analisis estradiol dalam plasma darah}

Pengambilan sampel darah untuk mengukur konsentrasi estradiol-17 $\beta$ (E2) plasma dilakukan setiap 10 hari sebelum penyuntikan hormon. Darah diambil dari dorsal aorta melalui pangkal ekor sebanyak 0,8-1 ml menggunakan syringe yang telah diberi heparin. Sampel darah yang diperoleh dimasukkan kedalam mikrotube 1,5 ml selanjutnya disentrifus dengan kecepatan 10.000 rpm selama 10 menit pada suhu $5^{\circ} \mathrm{C}$. Plasma darah dimasukkan kedalam mikrotube baru kemudian disimpan dalam freezer $\left(-20^{\circ} \mathrm{C}\right)$ untuk selanjutnya dilakukan pengukuran konsentrasi E2 plasma. Pengukuran konsentrasi E2 dalam plasma darah dilakukan menggunakan metode ELISA kit komersial (Catalog No. EIA 2693) yang diproduksi oleh Sigma.

\section{Preparasi dan pengamatan histologi gonad}

Preparasi histologi gonad dilakukan sebagai berikut: gonad dimasukkan dalam wadah berisi larutan bouin (campuran antara asam asetat glasial $5 \mathrm{ml}$ ditambah dengan formalin $40 \%$ sebanyak $25 \mathrm{ml}$ dan asam pikrat jenuh $75 \mathrm{ml}$ ). Selanjutnya gonad dicuci dengan air bersih dan dilakukan proses pembuatan preparat histologis mengacu pada metode Gunarso (1989). Struktur histologis diamati menggunakan mikroskop binokuler dengan pembesaran 100 dan 400 kali.

Penentuan nilai indeks kematangan gonad, indeks hepatosomatik, dan tingkat kematangan gonad

Pada akhir penelitian dilakukan pembedahan ikan uji untuk pengamatan struktur morfologis gonad, penghitungan nilai indeks kematangan gonad (IKG) dan indeks hepatosomatik (IHS) serta tingkat kematangan gonad (TKG). Bobot gonad dan hati ikan ditimbang menggunakan timbangan digital dengan tingkat ketelitian 0,01 g. Selanjutnya dilakukan analisis IKG, IHS, dan TKG.

IKG dihitung berdasarkan perbandingan bobot gonad dengan bobot ikan uji dengan mengacu kepada rumus Effendie (2002):

$$
\mathrm{IKG}=\frac{\text { bobot ovarium/testis }(\mathrm{g})}{\text { bobot tubuh ikan }(\mathrm{g})} \times 100
$$

IHS dihitung berdasarkan perbandingan bobot hati dan bobot tubuh ikan uji dengan mengacu kepada rumus Magalhaes et al. (2012):

$$
\mathrm{IHS}=\frac{\text { bobot hati }(\mathrm{g})}{\text { bobot tubuh ikan }(\mathrm{g})} \times 100
$$

TKG ikan ringau setelah perlakuan injeksi hormon dianalisis berdasarkan hasil pengamatan struktur morfologis dan histologis gonad yang mengacu pada ikan Perca fluviatilis (Treasurer \& Holliday 1981) seperti disajikan pada Tabel 3.

\section{Analisis data}

Nilai IKG, IHS, konsentrasi E2 plasma, dan pertumbuhan bobot dianalisis secara statistik menggunakan analisis ragam (ANOVA), dan jika terdapat pengaruh nyata dilanjutkan dengan uji Duncan dengan selang kepercayaan 95\% menggunakan program SPSS versi 22. Hasil pengamatan struktur morfologis dan histologis gonad dianalisis secara deskriptif. 
Tabel 3. Ciri-ciri perkembangan gonad ikan Perca fluviatilis (Treasurer \& Holliday 1981)

\begin{tabular}{|c|c|c|}
\hline TKG & Nama periode & Deskripsi \\
\hline I & Oogonoia & $\begin{array}{l}\text { Dua ovarium primordial dipisahkan oleh lapisan epitel; ovarium } \\
\text { mengandung sel primer }(3,3-6,7 \mu \mathrm{m}) \text {, oogonia }(13,3-20,0 \mu \mathrm{m}) \text {, dan oosit } \\
\text { primer }(13,3-60,0 \mu \mathrm{m})\end{array}$ \\
\hline II & Pre-vitellogenesis & $\begin{array}{l}\text { Ovarium lebih berkembang: ovarium diselimuti lamella ovigerous; } \\
\text { diameter oosit primer telah meningkat menjadi } 20,0-116,6 \mu \mathrm{m}\end{array}$ \\
\hline III & $\begin{array}{l}\text { Perkembangan awal } \\
\text { (vitellogenesis awal) }\end{array}$ & $\begin{array}{l}\text { Oosit berkembang dan berukuran } 162-346 \mu \mathrm{m} \text {; folikel terdiri atas lapisan } \\
\text { teka dan granulosa; chorion yang terdiri tunica propria, zona radiata dan } \\
\text { jaringan terlihat longgar; terjadi pembentukan vesikel kuning telur }\end{array}$ \\
\hline IV & $\begin{array}{l}\text { Perkembangan akhir } \\
\text { (vitellogenesis) }\end{array}$ & $\begin{array}{l}\text { Struktur oosit (bagian-bagian oosit) lebih jelas, diameter oosit mencapai } \\
773 \mu \mathrm{m} \text {; ooplasma hampir terisi penuh dengan granula kuning telur; } \\
\text { chorion lebih luas. }\end{array}$ \\
\hline
\end{tabular}

\section{Hasil}

\section{Indeks kematangan gonad}

Nilai indeks kematangan gonad (IKG) ikan uji sebelum dan setelah perlakuan penyuntikan disajikan pada Gambar 1. Nilai IKG pada awal penelitian adalah 0,12 , setelah dilakukan penyuntikan hormon terjadi peningkatan IKG pada semua perlakuan. IKG tertinggi pada akhir penelitian yaitu 2,38 $\pm 0,06$ terdapat pada perlakuan P4, diikuti oleh perlakuan P5 $(1,70 \pm 0,09)$, P3 $(1,59 \pm 0,02)$, P2 $(1,41 \pm 0,06)$, dan terendah pada perlakuan $\mathrm{P} 1 /$ kontrol $(0,77 \pm 0,09)$. Hal ini didukung oleh hasil analisis statistik yang menunjukkan IKG pada perlakuan P4 berbeda nyata $(p<0,05)$ dengan perlakuan lainnya.

\section{Indeks hepatosomatik}

Nilai indeks hepatosomatik (IHS) selama penelitian juga mengalami peningkatan setelah penyuntikan hormon yang disajikan pada Gambar 2. Nilai IHS pada awal penelitian adalah $1,16 \%$ dan meningkat setelah penyuntikan hormon (Gambar 2). IHS tertinggi pada akhir penelitian sebesar 3,09 $\pm 0,12 \%$ diperoleh pada perlakuan P4, diikuti perlakuan P3 (2,15 $\pm 0,08 \%)$, P2 $(1,77 \pm 0,11 \%)$, P5 $(1,63 \pm 0,15 \%)$ dan terendah pada perlakuan P1/kontrol (1,51 $\pm 0,09 \%)$. Hal ini didukung oleh hasil analisis statistik yang me- nunjukkan IHS pada perlakuan P4 berbeda nyata $(\mathrm{p}<0,05)$ dengan perlakuan lainnya.

\section{Tingkat kematangan gonad}

Tingkat kematangan gonad (TKG) ikan uji dianalisis berdasarkan hasil pengamatan struktur morfologis dan histologis gonad. Berdasarkan hasil pengamatan struktur morfologis gonad (Gambar 3) dan struktur histologis gonad (Gambar 4 dan 5) terlihat bahwa perkembangan gonad ikan uji paling baik diperoleh pada perlakuan P4 (PMSG-AD + 2 mg 5-HT).

Hasil pengamatan struktur morfologis gonad menunjukkan bahwa perlakuan P4 menghasilkan perkembangan gonad ikan uji yang lebih baik dengan ukuran yang lebih besar dibandingkan dengan perlakuan lainnya. Gonad ikan uji pada perlakuan P4 mengandung oosit yang terlihat dari permukaan gonad. Pada perlakuan P1 (kontrol), gonad ikan uji belum berkembang dan terlihat masih sangat tipis. Pada perlakuan P2, P3, dan P5 gonad ikan uji terlihat sudah berkembang dibandingkan dengan gonad ikan uji pada perlakuan P1 namun ukurannya lebih kecil dibandingkan gonad ikan uji pada perlakuan P4 (Gambar 3).

Struktur histologis gonad juga memperlihatkan bahwa perlakuan P4 memiliki struktur dan ukuran oosit yang berbeda dengan perlakuan 
lainnya. Oosit pada perlakuan P4 terlihat paling berkembang, dalam hal ini inti telur (nukleus) sudah terlihat dan terdapat nukleoli di sekitar nukleus oosit (Gambar 4). Selain itu, terlihat adanya butiran lemak dan granula kuning telur pada lapisan ooplasma sebagai hasil dari proses vite- llogenesis. Ukuran oosit terbesar yang didapatkan pada perlakuan ini mencapai $\pm 250 \mu \mathrm{m}$ dan didominasi oleh ukuran \pm 70 -100 $\mu \mathrm{m}$. Berdasarkan ciri-ciri tersebut maka perkembangan gonad ikan uji pada perlakuan P4 termasuk dalam tahap TKG III.

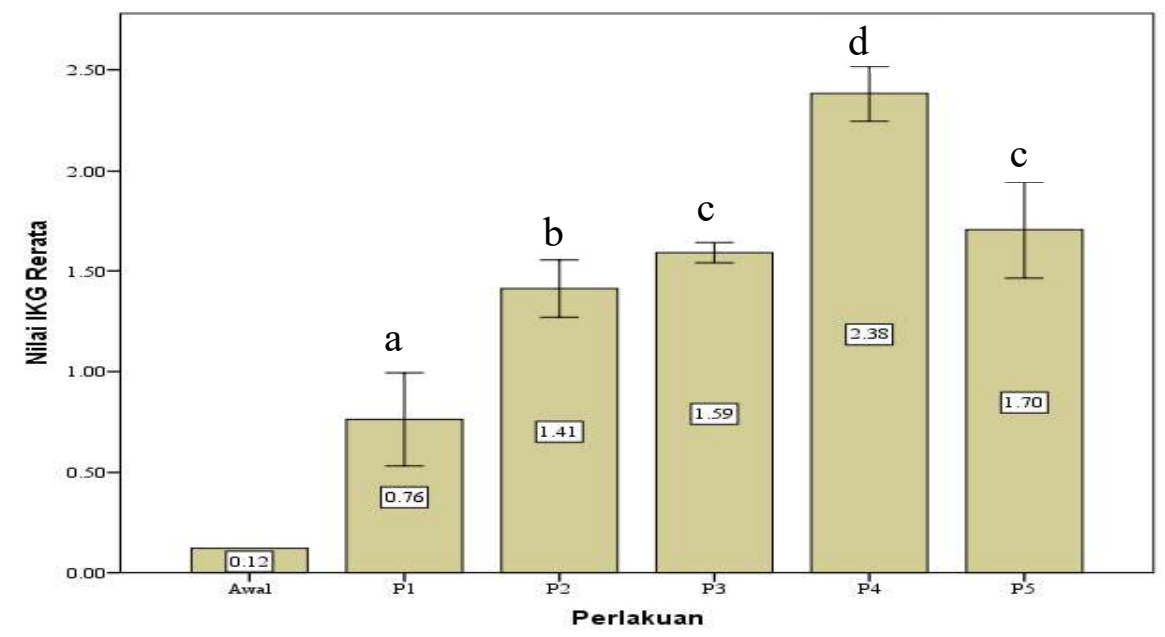

Gambar 1. Indeks kematangan gonad ikan ringau pada awal $(\mathrm{n}=1)$ dan akhir penelitian $(\mathrm{n}=3)$ dari semua perlakuan. P1: larutan $\mathrm{NaCl}$ 0,9\% (kontrol); P2: PMSG-AD; P3: PMSG-AD+0.2 mg 5-HT; P4: PMSG-AD+2 mg 5-HT; dan P5: PMSG-AD+4 mg 5-HT. Notasi huruf yang berbeda pada masing-masing perlakuan menunjukkan nilai berbeda nyata $(\mathrm{p}<0,05)$.

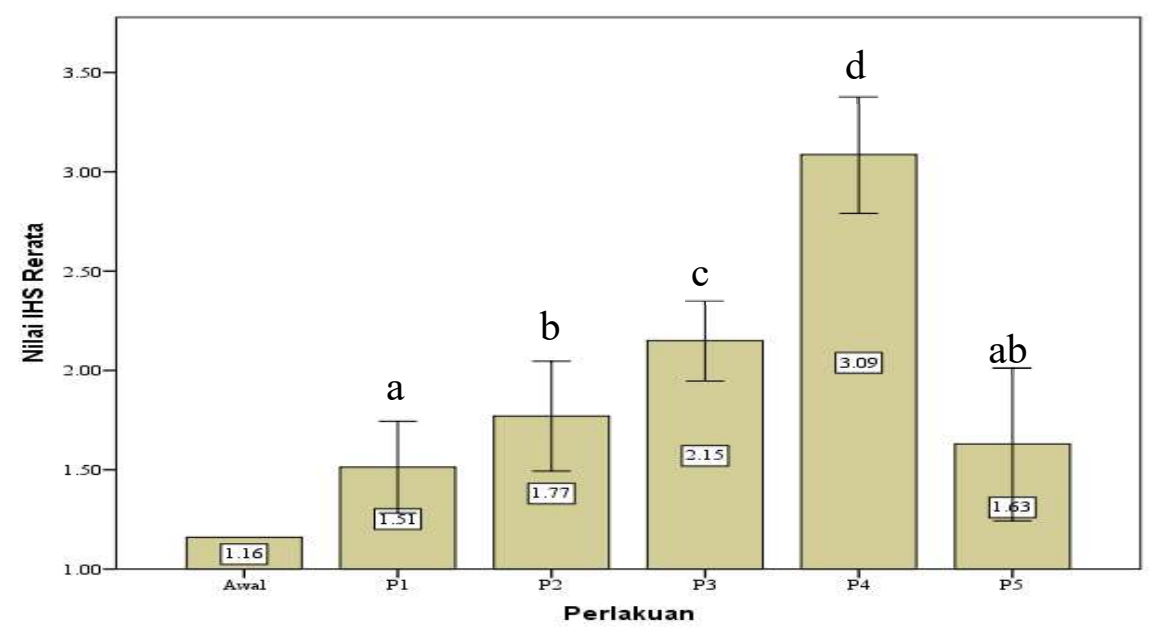

Gambar 2. Indeks hepatosomatik ikan ringau pada awal $(n=1)$ dan akhir penelitian $(n=3)$ semua perlakuan. P1: larutan $\mathrm{NaCl}$ 0,9\% (kontrol); P2: PMSG-AD; P3: PMSG-AD+0.2 mg 5-HT; P4: PMSG$\mathrm{AD}+2 \mathrm{mg}$ 5-HT; dan P5: PMSG-AD+4 mg 5-HT. Notasi huruf yang berbeda pada masingmasing perlakuan menunjukkan nilai berbeda nyata $(\mathrm{p}<0.05)$. 

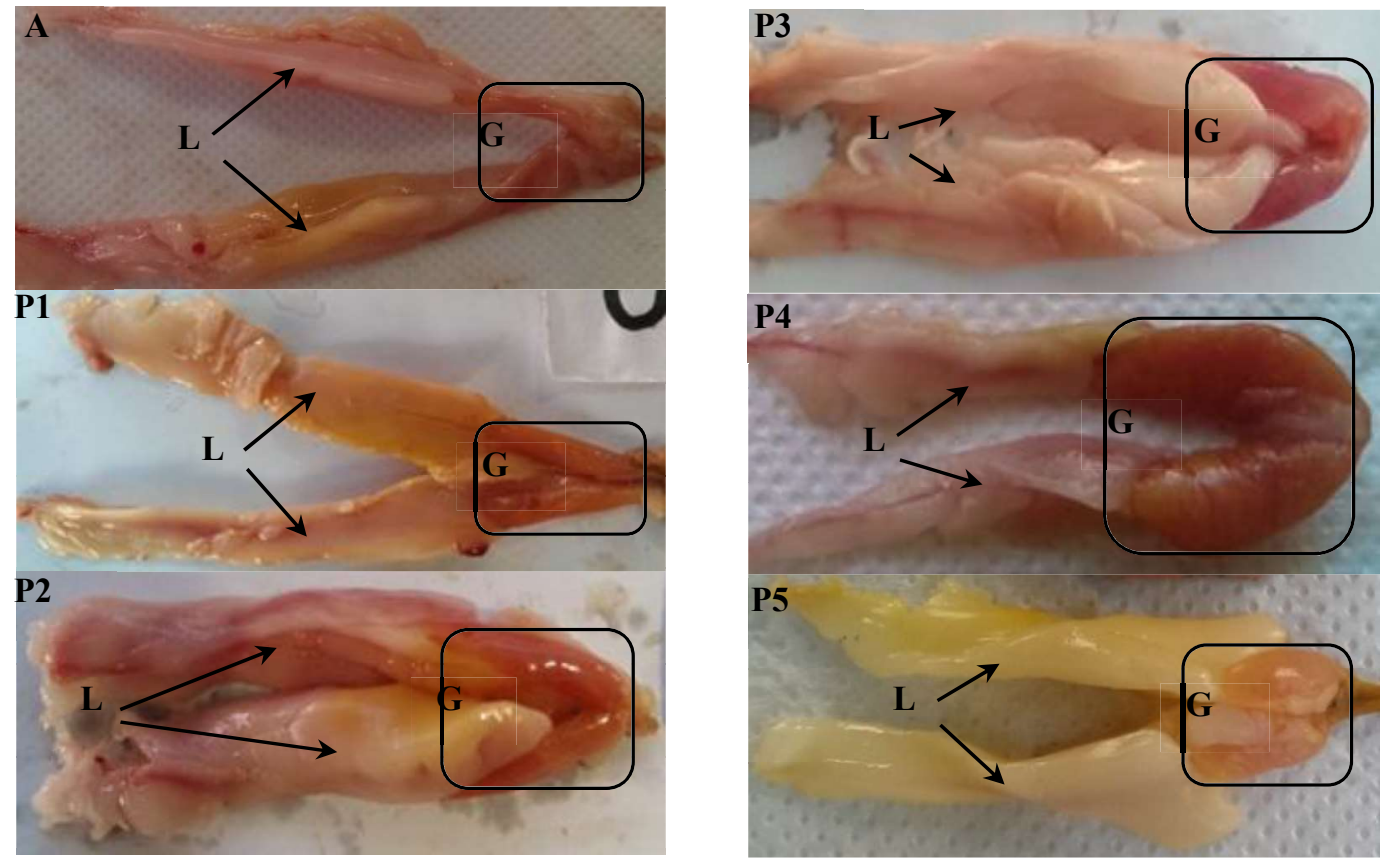

Gambar 3. Struktur morfologis gonad ikan ringau sebelum perlakuan induksi hormon (A) dan semua perlakuan (P1, P2, P3, P4 \& P5) pada akhir penelitian (hari ke-60). P1: larutan $\mathrm{NaCl}$ 0,9\%; P2: PMSG-AD; P3: PMSG-AD+0,2 mg 5-HT; P4: PMSG-AD+2 mg 5-HT; P5: PMSG-AD+4 mg 5-HT; G: gonad; dan L: lemak.

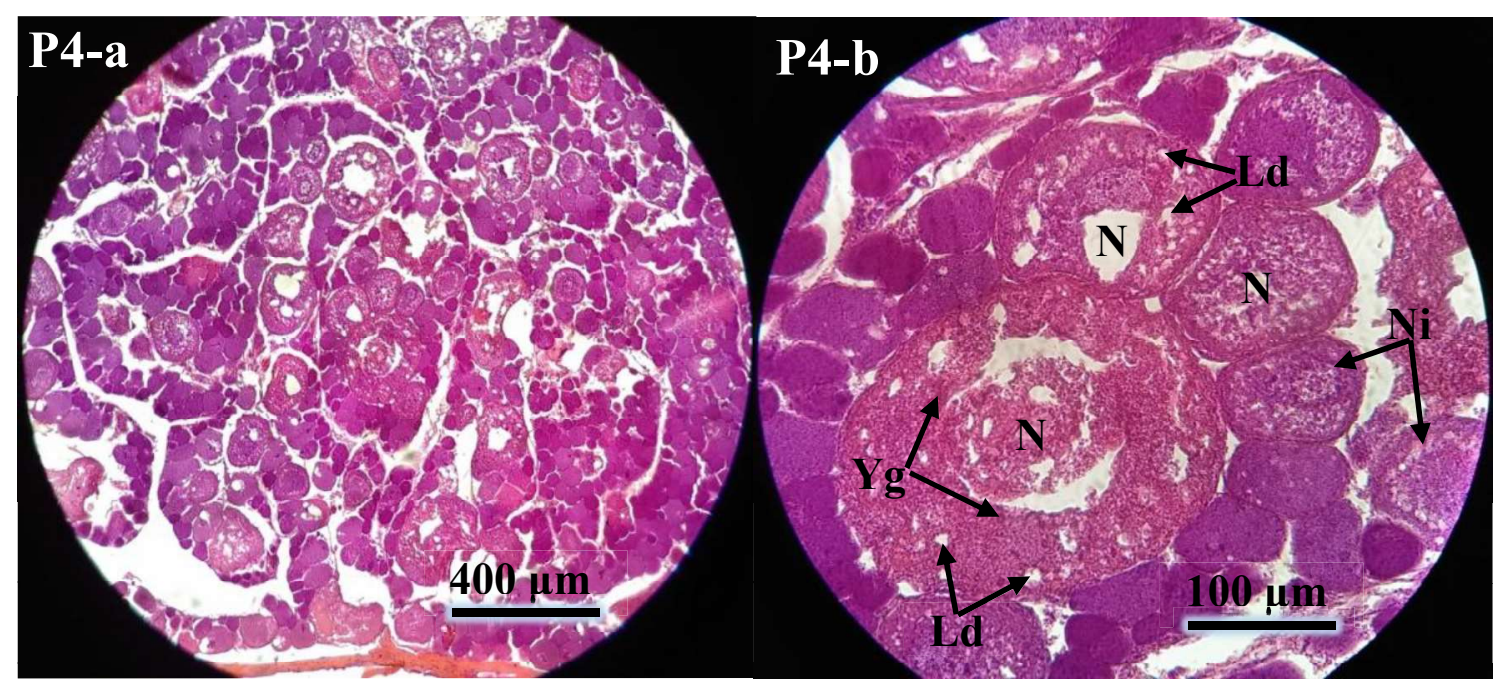

Gambar 4. Struktur histologis gonad ikan ringau perlakuan P4 dengan perbesaran 100X (P4-a) dan perbesaran 400X (P4-b). $\mathrm{Ni}=$ nukleoli; $\mathrm{N}=$ Nukleus; $\mathrm{Ld}=$ butiran lemak $\mathrm{Yg}=$ granula kuning telur 

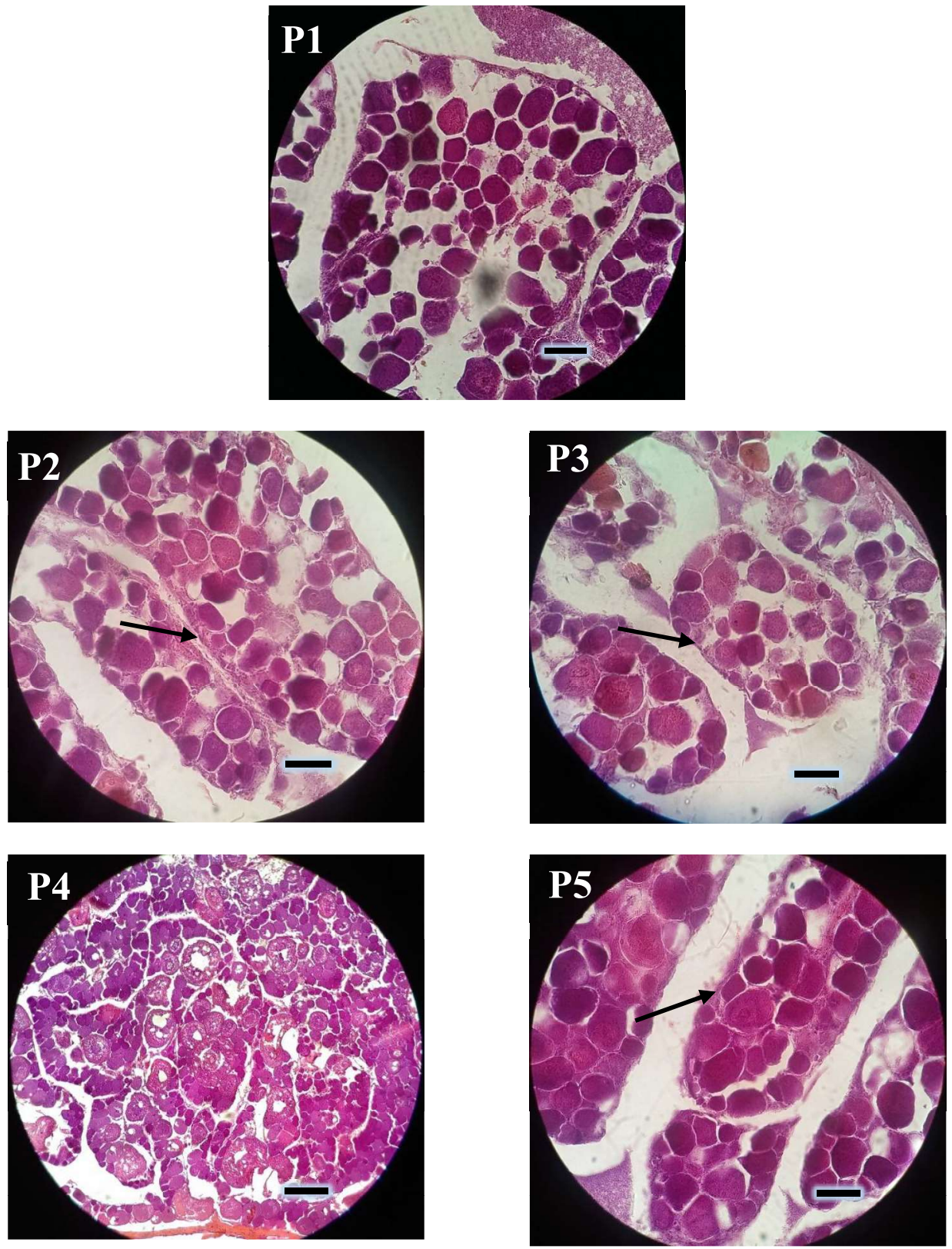

Gambar 5. Struktur histologis gonad ikan ringau semua perlakuan pada akhir penelitian (HE perbesaran 400X (P1, P2, P3 dan P5), skala bar $50 \mu \mathrm{m}$ dan perbesaran 100X (P4), skala bar $200 \mu \mathrm{m})$. P1: larutan $\mathrm{NaCl}$ 0,9\%; P2: PMSG-AD; P3: PMSG-AD+0.2 mg 5-HT; P4: PMSG-AD+2 mg 5-HT; dan P5: PMSG-AD+4 mg 5-HT. Tanda panah: lamella ovigerous

Pada perlakuan P1 (kontrol), gonad mengandung oosit (oogonia dan oosit primer) dengan ukuran $\pm 10-40 \mu \mathrm{m}$ dan didominasi oleh ukuran $\pm 25 \mu \mathrm{m}$. Pada perlakuan ini, tingkat kematangan gonad masih berada pada tahap TKG I. Pada perlakuan penyuntikan hormon lainnya baik dengan PMSG-AD (P2) maupun yang dikombinasikan dengan 5-HT dengan dosis 0,2 mg (P3) dan $4 \mathrm{mg}$ (P5), tingkat kematangan gonad ikan uji yang didapatkan berada pada tahap TKG II. Pada tahap ini, ukuran oosit sudah lebih berkembang (diameter $\pm 20-65 \mu \mathrm{m}$ ) dibandingkan dengan perlakuan P1. Ukuran terbesar diameter oosit yang teramati pada ketiga perlakuan tersebut (P2, P3 dan P5) sebesar $\pm 65 \mu \mathrm{m}$, namun inti telur belum terlihat dengan jelas (Gambar 5). 


\section{Konsentrasi estradiol-17 $\beta$ (E2) plasma}

Pada awal penelitian (sebelum perlakuan penyuntikan), konsentrasi E2 rata-rata didapat-

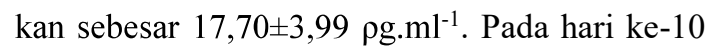
hingga ke-20, secara umum terjadi penurunan konsentrasi E2 pada semua perlakuan. Konsentrasi E2 tertinggi pada hari ke-10 terjadi pada perlakuan P1 $\left(17,81 \pm 6,07 \rho g \cdot \mathrm{ml}^{-1}\right)$ dan terendah pada perlakuan P2 $\left(0,14 \pm 0,00 \rho g \cdot \mathrm{ml}^{-1}\right)$. Pada hari ke-20, konsentrasi E2 tertinggi terjadi pada perlakuan P5 $\left(22,25 \pm 8,28 \rho g . \mathrm{ml}^{-1}\right)$ dan terendah pada perlakuan P1 $\left(2,28 \pm 0,87 \rho g \cdot \mathrm{ml}^{-1}\right)$. Pada hari ke30, konsentrasi E2 sudah mulai meningkat dibandingkan hasil pengamatan sebelumnya. Namun nilainya masih lebih kecil bila dibandingkan dengan sebelum perlakuan penyuntikan (awal) kecuali pada perlakuan P4. Peningkatan konsentrasi E2 dengan nilai yang relatif lebih tinggi dibandingkan sebelum penyuntikan mulai terjadi pada hari ke-40 kecuali pada perlakuan P1. Pada hari ke-50 dan ke-60, secara umum konsentrasi E2 semakin meningkat pada semua perlakuan meskipun terjadi fluktuasi pada hari ke-60. Konsentrasi E2 tertinggi pada hari ke-60 diperoleh pada perlakuan P4 $\left(37,14 \pm 2,99 \rho g \cdot \mathrm{ml}^{-1}\right)$, diikuti perlakuan P2 $\left(29,46 \pm 2,00 \rho g \cdot \mathrm{ml}^{-1}\right)$, kemudian perlakuan P5 $\left(29,24 \pm 3,29 \rho g . \mathrm{ml}^{-1}\right)$, P1 $(28,48 \pm 2,74$ pg. $\left.\mathrm{ml}^{-1}\right)$, dan terendah perlakuan P3 $(22,25 \pm 3,22$ $\left.\rho g . \mathrm{ml}^{-1}\right)$. Berdasarkan analisis statistik, konsentrasi E2 perlakuan P4 pada akhir penelitian berbeda nyata $(\mathrm{p}<0.05)$ dibandingkan dengan perlakuan lainnya (Gambar 6).

\section{Pertumbuhan bobot}

Hasil pengamatan pertumbuhan bobot pada semua perlakuan selama penelitian disajikan pada Gambar 7. Pertumbuhan bobot ikan uji yang diberi perlakuan hormon (P2, P3, P4 dan P5) lebih baik dibandingkan dengan tanpa perla-

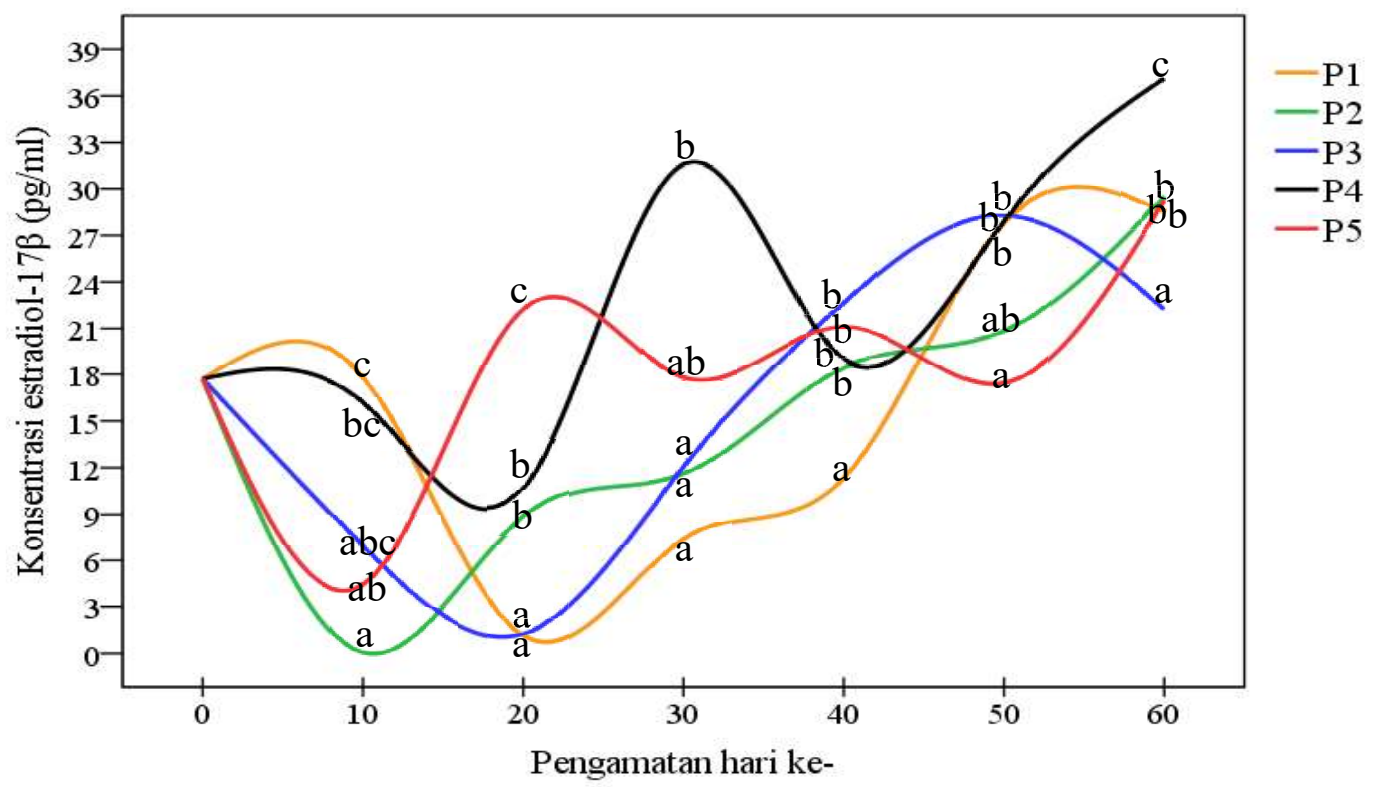

Gambar 6. Pola konsentrasi estradiol-17 $\beta$ (E2) dalam darah ikan ringau sebelum (hari ke-0) dan sesudah induksi hormon (hari ke-10 sampai 60). P1: larutan NaCl 0,9\%; P2: PMSG-AD; P3: PMSG$\mathrm{AD}+0.2 \mathrm{mg}$ 5-HT; P4: PMSG-AD+2 mg 5-HT; dan P5: PMSG-AD+4 mg 5-HT. Notasi huruf yang berbeda pada setiap waktu pengamatan menunjukkan nilai berbeda nyata $(p<0,05)$ 


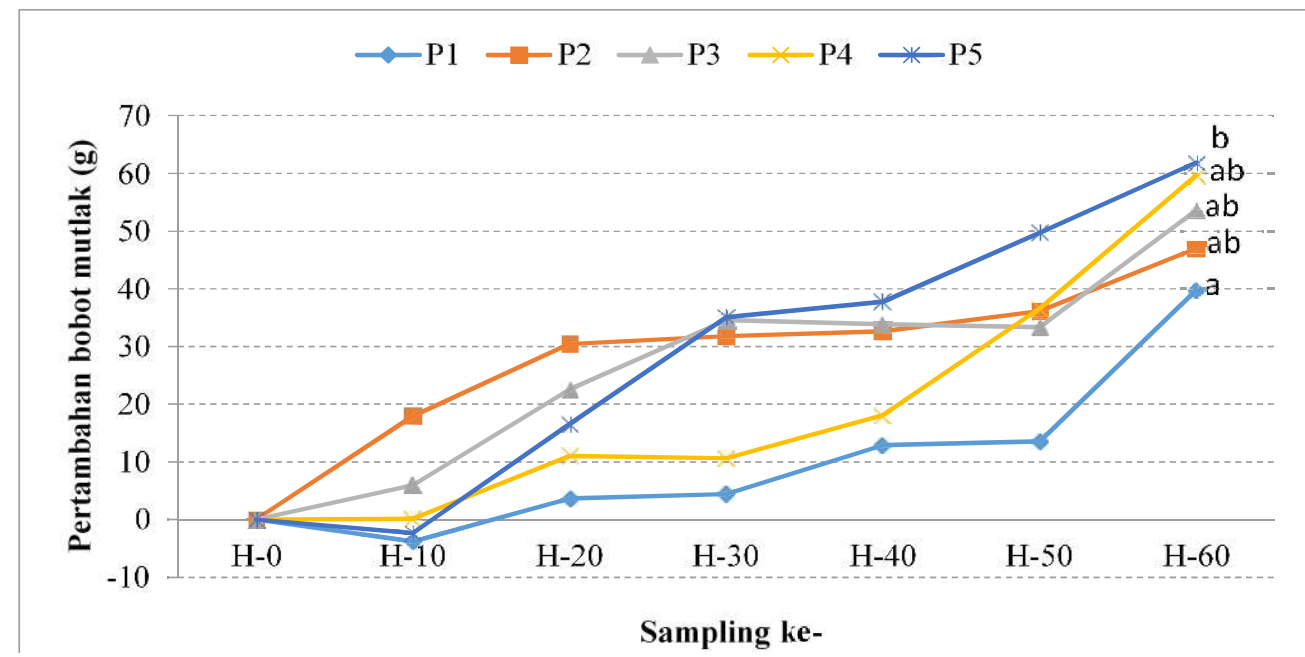

Gambar 7. Pertumbuhan bobot ikan ringau setiap perlakuan selama penelitian $(\mathrm{n}=3)$. $\mathrm{P} 1$ : larutan $\mathrm{NaCl}$ 0,9\%; P2: PMSG-AD; P3: PMSG-AD+0.2 mg 5-HT; P4: PMSG-AD+2 mg 5-HT; dan P5: PMSG-AD+4 mg 5-HT. Notasi huruf yang berbeda menunjukkan nilai pertumbuhan bobot berbeda nyata $(\mathrm{p}<0.05)$ pada pengamatan hari ke- 60 .

kuan hormon/kontrol (P1). Nilai pertumbuhan bobot tertinggi pada akhir penelitian diperoleh pada perlakuan P5 $(61,87 \pm 10,30 \mathrm{~g})$ dan diikuti oleh perlakuan P4 $(59,67 \pm 1,48 \mathrm{~g})$, P3 $(53,57 \pm$ $13,61 \mathrm{~g}), \mathrm{P} 2(47,00 \pm 15,44 \mathrm{~g})$ dan terendah pada perlakuan P1 kontrol $(39,77 \pm 7,13$ g). Secara statistik, pertumbuhan bobot pada perlakuan P5 berbeda nyata $(\mathrm{p}<0,05)$ dengan perlakuan $\mathrm{P} 1$ (kontrol) namun tidak berbeda nyata $(p>0,05)$ dengan perlakuan induksi hormon lainnya ( $\mathrm{P} 2$, P3. dan P4).

\section{Pembahasan}

Berdasarkan hasil pengamatan parameter indeks kematangan gonad, indeks hepatosomatik, konsentrasi estradiol-17 $\beta$, struktur morfologis dan histologis gonad, perlakuan penyuntikan PMSG-AD yang dikombinasikan dengan $2 \mathrm{mg}$ serotonin (5-HT) (perlakuan P4) merupakan perlakuan terbaik pada penelitian ini. Pada perlakuan $\mathrm{P} 4$, nilai masing-masing parameter perkembangan gonad yang didapatkan merupakan nilai tertinggi dibandingkan perlakuan lainnya. Peng- gunaan kombinasi hormon perlakuan P4 meningkatkan nilai IKG dari 0,76 (kontrol) menjadi 2,38 (Gambar 1) dan nilai IHS dari 1,51\% (kontrol) menjadi 3,09\% (Gambar 2). Peningkatan konsentrasi E2 pada perlakuan P4 yaitu sebesar 19,44 $\rho g . \mathrm{ml}^{-1}(109,83 \%)$ lebih tinggi dibandingkan dengan perlakuan P1 (kontrol) yaitu sebesar 10,78 pg. $\mathrm{ml}^{-1}(60,90 \%)$ (Gambar 6) sehingga perlakuan P4 menghasilkan perkembangan gonad paling baik hingga mencapai TKG III (Gambar 4).

Penggunaan hormon PMSG dan AD dapat meningkatkan kinerja reproduksi beberapa spesies ikan. FSH yang terdapat dalam hormon PMSG bekerja pada lapisan teka oosit untuk merangsang terjadinya sintesis testosteron. Dalam lapisan granulosa, testosteron diubah oleh enzim aromatase menjadi E2 yang selanjutnya diangkut ke hati dan merangsang hati untuk mensintesis vitellogenin (Yaron \& Levavi-Sivan 2011). Antidopamin (AD) merupakan bahan kimiawi yang berfungsi menghambat kerja dopamin. Dopamin merupakan neurotransmitter yang bekerja menghambat sekresi GnRH (FSHRH) dari hipotala- 
mus (Cerda-Reverter \& Canosa 2009, Kah 2009, Van der Kraak 2009), menghambat sekresi FSH dari pituitari dan dari sel gonadotropin melalui reseptor dopamin D2 (Vacher et al. 2000, Vacher et al. 2002) serta menghambat pematangan gonad melalui aksinya sebagai faktor penghambat pelepasan gonadotropin (Gonadotropin releaseinhibiting factor/GRIF) (Dufour et al. 2005). Dengan penambahan antidopamin maka sekresi FSHRH dapat meningkat dan memengaruhi terjadinya proses vitellogenesis.

Hormon PMSG dan AD telah digunakan pada beberapa spesies ikan untuk merangsang perkembangan gonadnya. Penggunaan PMSG 5 IU. $\mathrm{kg}^{-1}$ bobot tubuh melalui penyuntikan mampu mempercepat proses pematangan gonad dan meningkatkan indeks kematangan gonad ikan lele dumbo Clarias sp. (Mayasari 2012); memacu pembentukan oosit dan pematangan gonad ikan Tor soro muda dengan dosis pemberian 4 IU. $\mathrm{kg}^{-1}$ bobot tubuh (Wahyuningsih 2012); dan meningkatkan kadar E2, IGS, IHS, diameter telur serta meningkatkan perkembangan gonad hingga TKG IV belut (Monopterus albus) dengan pemberian 20 IU PMSG dan 0,01 mg antidopamin per $\mathrm{kg}$ bobot tubuhnya (Putra 2013). Pada penelitian ini, penggunaan 20 IU PMSG dan $10 \mathrm{mg}$ AD (perlakuan P2) pada ikan ringau (Datnioides microlepis) melalui penyuntikan secara intramuskular dapat meningkatkan nilai IKG dan IHS dibandingkan tanpa pemberian hormon (kontrol/P1). Namun demikian, penambahan serotonin (5-HT) ke dalam formulasi hormon tersebut (perlakuan P3, P4 dan P5) dapat menghasilkan nilai IKG, IHS, konsentrasi E2, dan tingkat kematangan gonad yang relatif lebih tinggi. Hal ini menunjukkan bahwa serotonin (5-HT) memiliki peranan dalam merangsang proses perkembangan gonad ikan ringau pada penelitian ini.
Serotonin (5-HT) telah digunakan pada beberapa spesies organisme akuatik untuk merangsang perkembangan gonadnya. Serotonin (5HT) dapat menginduksi pematangan oosit kerang zebra Dreissena polymorpha (Fong et al. 1994), meningkatkan indeks ovarium dan ukuran oosit lobster merah Procambarus clarckii (Kulkarni et al., 1992), merangsang perkembangan ovarium dan testis kepiting rawa Uca pugilator (Richardson et al., 1991), merangsang sekresi GtH pada ikan Croaker Atlantik Micropogonias undulates (Khan \& Thomas 1992), ikan komet Carassius auratus (Somoza et al. 1988) dan ikan mas Prusia Carassius gibelio Bloch (Sokolowska-Mikolajczyk et al. 2015), menginduksi sekresi GnRH pada ikan mas Ciprinus carpio (Yu et al. 1991) dan ikan Pagrus major (Senthilkumaran et al. 2001), serta meningkatkan produksi estradiol$17 \beta$ pada ikan medaka Oryzias latipes (Iwamatsu et al. 1993).

Penambahan serotonin (5-HT) dengan dosis tertentu dalam kombinasi hormon perlakuan pada penelitian ini tampaknya memberikan efek positif terhadap perkembangan gonad ikan ringau dengan memengaruhi kinerja sel gonadotropin dalam melepaskan GnRH. Pada penelitian ini, penambahan $2 \mathrm{mg} 5$-HT per-kg bobot tubuh ikan ringau merupakan dosis terbaik dalam kombinasinya dengan 20 IU PMSG dan 10 mg AD (perlakuan P4). Penambahan 0,2 mg 5-HT dalam kombinasi hormon perlakuan P3 belum memberikan hasil yang maksimal. Hal ini dapat dilihat dari nilai IKG, IHS, konsentrasi E2, dan tingkat perkembangan gonadnya yang masih rendah. Nilai IKG $(1,59 \pm 0,02 \%)$, IHS $(2,15 \pm 0,08 \%)$, dan konsentrasi E2 $\left(29,24 \pm 3,29 \rho \mathrm{g} \cdot \mathrm{ml}^{-1}\right)$ pada perlakuan P3 lebih rendah dibandingkan IKG $(2,38$ $\pm 0,06 \%)$, IHS $(3,09 \pm 0,12 \%)$, dan konsentrasi E2 $\left(37,14 \pm 2,99 \rho g \cdot \mathrm{ml}^{-1}\right)$ pada perlakuan P4. Demikian pula dengan tingkat perkembangan gonad- 
nya. Pada perlakuan P3 perkembangan gonad ikan uji masih dalam tahap pre-vitellogenesis (TKG II), sedangkan pada perlakuan P4 gonad ikan uji sudah memasuki TKG III yang ditandai dengan terdapatnya butiran lemak dan granula kuning telur dalam ooplasma (Gambar 5). Hal ini menunjukkan bahwa proses vitellogenesis telah terjadi pada ikan uji perlakuan P4. Vitellogenesis merupakan proses pembentukan bakal kuning telur (vitellogenin) yang terjadi di hati kemudian dibawa oleh aliran darah menuju gonad dan secara selektif terjadi penyerapan oleh lapisan folikel oosit (Lubzens et al. 2010).

Pada penambahan dosis 5-HT yang lebih besar (4 mg. $\mathrm{kg}^{-1}$ bobot tubuh) dalam kombinasi hormon pada perlakuan P5 ternyata tidak memberikan hasil yang lebih baik dibandingkan pada perlakuan P4. Pada perlakuan ini, gonad ikan uji masih dalam periode pre-vitellogenesis (TKG II) dengan nilai IKG sebesar 1,70 $\pm 0,09$; nilai IHS sebesar 1,63 $\pm 0,15 \%$ serta konsentrasi E2 sebesar $22,25 \pm 8,28 \rho \mathrm{g} \cdot \mathrm{ml}^{-1}$ pada akhir penelitian. Nilai parameter perkembangan gonad tersebut lebih rendah dibandingkan dengan hasil yang diperoleh pada perlakuan P4. Hal ini kemungkinan disebabkan oleh jumlah 5-HT dalam kombinasi hormon yang digunakan pada perlakuan ini melebihi kebutuhan ikan sehingga diduga memberikan efek negatif terhadap kinerja sel gonadotropin dalam tubuh ikan ringau. Kelebihan serotonin dalam tubuh ikan dikurangin melalui oksidase monoamine (Kreke \& Dietrich 2008) dan dikeluarkan oleh tubuh melalui sistem ekskresi (Mylonas et al. 2010). Menurut Cerda et al. (1998a), efek negatif 5-HT terhadap pematangan oosit terutama pada pembelahan miosis sangat bergantung pada masuknya tahap akhir pertumbuhan oosit menuju pematangan yang diaktifkan oleh steroid yang menginduksi pematangan (Maturation-inducing Steroid/MIS). Pada ikan Fundulus heteroclitus 5-HT yang diberikan secara in vitro dengan dosis $10^{-4} \mathrm{M}(\sim 0,213 \mathrm{mg})$ dapat menghambat pematangan oosit (Cerda et al. 1998b). Pada ikan ringau yang diamati pada penelitian ini, efek negatif 5-HT diduga terjadi pada dosis yang lebih tinggi yaitu $4 \mathrm{mg}$ (perlakuan P5). Namun berbeda halnya pada ikan kakap Atlantik (Micropogonias undulatus); dosis 5-HT yang lebih besar yaitu $20 \mu \mathrm{g} . \mathrm{g}^{-1}\left(\sim 20 \mathrm{mg} \cdot \mathrm{kg}^{-1}\right)$ yang diberikan bersamaan dengan LHRHa 20 ng. $\mathrm{g}^{-1}$ $\left(\sim 0,02 \mathrm{mg} \cdot \mathrm{kg}^{-1}\right)$ melalui penyuntikan intraperitoneal tidak memberikan reaksi negatif, pada dosis tersebut 5-HT dapat meningkatkan kadar gonadotropinnya (Khan \& Thomas 1992). Adanya perbedaan perkembangan gonad yang didapatkan dari penggunaan serotonin pada beberapa spesies ikan tampaknya berhubungan dengan tingkat kematangan individu ikan tersebut serta kebutuhan 5-HT pada masing-masing spesies ikan yang berbeda-beda. Kreke \& Dietrich (2008) menyatakan bahwa 5-HT memberikan pengaruh pada organ target serta jalur yang berbeda dan tampaknya spesifik berdasarkan spesies dan mungkin juga bergantung pada jenis kelamin dan atau tingkat perkembangan dan reproduksi individu ikan.

Pada pengamatan pertumbuhan bobot ikan uji, diperoleh nilai tertinggi pada akhir penelitian pada perlakuan P5 (PMSG-AD + $4 \mathrm{mg}$ 5 -HT) yaitu sebesar $61,87 \pm 10,30 \mathrm{~g}$. Nilai ini relatif lebih tinggi dibandingkan pada perlakuan P4 (PMSG-AD + 2 mg 5-HT) yaitu sebesar $59,67 \pm 1,48 \mathrm{~g}$, namun secara statistik kedua nilai tersebut tidak berbeda nyata $(p>0,05)$. Secara umum, pertumbuhan bobot ikan uji pada perlakuan P5 tidak berbeda nyata $(\mathrm{p}>0,05)$ dengan semua perlakuan injeksi menggunakan hormon baik PMSG dan AD (P2) maupun yang ditambahkan dengan serotonin (5-HT) sebesar 0,2g (P3) dan 2 g (P4), namun berbeda nyata $(\mathrm{p}<0,05)$ dengan perlakuan kontrol. Hal ini berhubungan 
dengan perkembangan gonad ikan ringau yang diberi perlakuan penyuntikan hormon (P2, P3, P4, dan P5) yang lebih baik dibandingkan dengan perlakuan kontrol (P1). Effendie (2002) menyatakan bahwa bobot tubuh induk ikan betina akan meningkat seiring dengan perkembangan gonadnya. Perkembangan gonad pada perlakuan penyuntikan hormon (P2, P3 P4 dan P5) lebih baik dengan kematangan gonad berada pada TKG II-III dibandingkan perlakuan kontrol (P1) dengan gonadnya yang masih belum berkembang dan berada pada TKG I (Gambar 4).

\section{Simpulan}

Penyuntikan ikan ringau dengan serotonin (5-HT) sebanyak $2 \mathrm{mg}$ yang dtambahkan ke dalam hormon Pregnant Mare Serum Gonadotropin sebanyak $20 \mathrm{IU}$ dan antidopamin $10 \mathrm{mg}$ untuk setiap $1 \mathrm{~kg}$ bobot tubuhnya dapat meningkatkan nilai indeks kematangan gonad, indeks hepatosomatik, konsentrasi estradiol-17 $\beta$ (E2), dan menghasilkan perkembangan gonad paling baik hingga mencapai TKG III. Peningkatan dosis serotonin menjadi $4 \mathrm{mg}$ dalam kombinasi hormon tersebut dapat memberikan efek negatif terhadap kinerja sel gonadotropin dalam melepaskan GnRH sehingga perkembangan gonad ikan tidak maksimal.

\section{Persantunan}

Ucapan terima kasih penulis sampaikan kepada pimpinan Balai Penelitian dan Pengembangan Budidaya Ikan Hias, Depok yang telah menyediakan sarana dan prasarana serta dukungan sehingga penelitian ini dapat dilaksanakan. Terima kasih juga penulis sampaikan kepada Bapak Sawung Cindelaras, Bapak Acep Sutisna, Ibu Dinar Tri Agustina beserta rekan yang lain yang telah membantu dalam pelaksanaan penelitian ini. Makalah ini merupakan bagian dari tesis dengan judul "Induksi maturasi ikan ringau

(Datnioides microlepis) secara hormonal”.

\section{Daftar pustaka}

Bolamba D, Mattont P, Estrada R, Dufour JJ. 1992. Effects of pregnant mare's serum gonadotropin treatment on follicular populations and ovulation rates in prepubertal gilts with two morphologically different ovarian types. Journal of Animal Science, 70(6): 1916-1922.

Cerda J, Reich G, Wallace RA, Selman K. 1998a. Serotonin inhibition of steroidinduced meiotic maturation in the teleost Fundulus heteroclitus: Role of cyclic AMP and protein kinases. Molecular Reproduction and Development, 49(3): 333341.

Cerda J, Subhedar N, Reich G, Wallace RA, Selman K. 1998b. Oocyte sensitivity to serotonergic regulation during the follicular cycle of the teleost Fundulus heteroclitus. Biology of Reproduction, 59(1): 53-61.

Cerda-Reverter JM, Canosa LF. 2009. Neuroendocrine systems of the fish brain. In: Bernier NJ, Van der Kraak G, Farrell AP, Brauner CJ (eds.). Fish Physiology volume 28: Fish Neuroendocrinology. Academic Press. Burlington. p 3-74.

Dufour S, Weltzien F-A, Sebert M-E, Le Belle N, Vidal B, Vernier P, Pasqualini C. 2005. Dopaminergic inhibition of reproduction in teleost fishes, ecophysiological and evolutionary implications. Annals NewYork Academy Science, 1040: 9-21.

Effendie MI. 2002. Biologi perikanan. Yayasan Pustaka Nusatama. Yogyakarta. 163 hlm.

Fong PP, Kyozuka K, Abdelghani H, Hardege JD, Ram JL. 1994. In vivo and in vitro induction of germinal vesicle breakdown in a freshwater bivalve, the zebra mussel Dreissena polymorpha (Pallas). The Journal of Experimental Zoology, 269(5): 467474.

Gallego V, Mazzeo I, Vílchez MC, Peñaranda DS, Carneiro PCF, Pérez L, Asturiano JF. 2012. Study of the effects of thermal regime and alternative hormonal treatments on the reproductive performance of European eel males (Anguilla anguilla) during induced sexual maturation. Aquaculture, 354-355: 7-16.

Gunarso W. 1989. Mikroteknik. Pusat Antar Universitas Ilmu Hayat. Institut Pertanian Bogor. Bogor. 117 hlm. 
Iwamatsu T, Toya Y, Ouchi H, Aoyama T, Yoneima J, Kondo T, Imai K, Hattori H, Ikegami S, Onda M. 1992. Characterization of a low molecular weight factor in chicken serum with oocyte maturationinducing activity. Biomedical Research, 13(6): 429-437.

Iwamatsu T, Toya Y, Sakai N, Terada Y, Nagata R, Nagahama Y. 1993. Effect of 5-hydroxytryptamine on steroidogenesis and oocyte maturation in preovulatory follicles of the medaka, Oryzias latipes. Development, Growth \& Differentiation 35(6): 625-630.

Kah O. 2009. Endocrine targets of the hypothalamus and pituitary. In: Bernier NJ, Van der Kraak G, Farrell AP, Brauner CJ (eds.). Fish Physiology volume 28: Fish Neuroendocrinology. Academic Press. Burlington. pp 75-112.

Keys SJ, Crocos PJ. 2006. Domestication, growth and reproductive performance of wild, pond and tank-reared brown tiger shrimp Penaeus esculentus. Aquaculture, 257(1-4): 232-240.

Khan IA, Thomas P. 1992. Stimulatory effects of serotonin on maturational gonadotropin release in the Atlantic croaker, Micropogonias undulatus. General and Comparative Endocrinology, 88(3): 388-396.

Kottelat M, Whitten AJ, Kartikasari SN, Wirjoatmodjo S. 1993. Freshwater Fishes of Western Indonesia and Sulawesi. Periplus Editions. Jakarta 158 p.

Kreke N, Dietrich DR. 2008. Physiological endpoints for potential SSRI interactions in fish. Critical Reviews in Toxicology, 37(3): 215-247.

Kulkarni GK, Nagabhushanam R, Amaldoss G, Jaiswal RG, Fingerman M. 1992. In vivo stimulation of ovarian development in the red swamp crayfish, Procambarus clarkii (Girard), by 5-hydroxytryptamine. Invertebrate Reproduction and Development, 21(3): 231-239.

Lorenzen K, Beveridge MCM, Mangel M. 2012. Cultured fish: integrative biology and management of domestication and interactions with wild fish. Cambridge Philosophical Society. Biological Reviews, 87(3): 639-660.

Lubzens E, Young G, Bobe J, Cerda J. 2010. Oogenesis in teleost: how fish eggs are formed. General and Comparative Endocrinology, 165(3): 367-389.
Magalhaes T, Mossolin EC, Mantelatto FL. 2012. Gonadosomatic and hepatosomatic indexes of the freshwater shrimp Macrobrachium olfersii (Decapoda, Palaemonidae) from São Sebastião Island, Southeastern Brazil. Pan-American Journal of Aquatic Sciences, 7(1): 1-9.

Mananos E, Duncan N, Mylonas C. 2009. Reproduction and control of ovulation, spermiation and spawning in cultured fish. In: Cabrita E, Robles V, Herraez P (eds.). Methods in Reproductive Aquaculture: Marine and Freshwater Species. CRC Press, Florida. p 3-80.

Mayasari N. 2012. Pemacuan kematangan gonad ikan lele dumbo (Clarias sp.) betina dengan kombinasi hormon pmsg dan Spirulina. Tesis. Sekolah Pascasarjana Institut Pertanian Bogor. Bogor. 85 hlm.

Mylonas CC, Fostier A, Zanuy S. 2010. Broodstock management and hormonal manipulations of fish reproduction. General and Comparative Endocrinology, 165(3): 516-534.

Nagahama Y, Matsuhisa A, Iwamatsu T, Sakai N, Fukada S. 1991. A mechanism for the action of pregnant mare serum gonadotropin on aromatase activity in the ovarian follicle of the medaka, Oryzias latipes. The Journal of Experimental Zoology, 259(1): 53-58.

Podhorec P, Kouril J. 2009. Induction of final oocyte maturation in cyprinidae fish by hypothalamic factors: A review. Veterinarni Medicina, 54(3): 97-110.

Prazad P, Ogawa S, Parhar IS. 2015. Review: Role of serotonin in fish reproduction. Frontiers in Neuroscience 195(9): 1-9.

Putra WKA. 2013. Induksi maturasi belut sawah (Monopterus albus) secara hormonal. Tesis. Sekolah Pascasarjana Institut Pertanian Bogor. Bogor. 54 hlm.

Richardson HG, Deecaraman M, Fingerman M. 1991. The effect of biogenic amines on ovarian development in the fiddler crab, Uca pugilator. Comparative Biochemistry and Physiology, 99(1/2): 53-56.

Rohmy S, Solichah L, Satyani D. 2011. Perkembangan reproduksi dan stimulasi hormonal ikan hias tigerfish (Datnioides microlepis) di lingkungan budidaya. In: Nainggolan C, Sondita FM, Sudrajat A, Masengi S. Sipahutar YH. Saifurridal (ed.). Prosiding Seminar Nasional Perikanan Indonesia 2011. Sekolah Tinggi Perikanan. Jakarta. p. 316-322. 
Rohmy S, Satyani D, Cindelaras S, Himawan Y. 2012. Perkembangan gonad ikan hias tigerfish (Datnioides microlepis) pada tiga kelompok ukuran berbeda. In: Haryanti, Rachmansyah, Sugama K, Parenrengi A, Sudrajat A, Imron, Sunarto A, Sumiarsa GS, Azwar ZI, Kristanto AH (ed.). Indoaqua-Forum inovasi teknologi akuakultur 2012. Pusat Penelitian dan Pengembangan Perikanan Budidaya, BRKP-KKP. Jakarta. p. 369-379.

Rohmy S, Satyani D, Cindelaras S, Himawan Y. 2014. Perkembangan gonad ikan ringau (Datnioides microlepis) pada salinitas berbeda. In: Sugama K, Kusnendar E, Rachmansyah, Giri NA, Yuhana M, Kristanto AH, Imron, Radiarta IN, Dewi RRSPS (ed.). Forum inovasi teknologi akuakultur 2014. Pusat Penelitian dan Pengembangan Perikanan Budidaya, BRKP-KKP. Jakarta. p. 253-259.

Senthilkumaran B, Okuzawa K, Gen K, Kagawa H. 2001. Effects of serotonin, GABA and neuropeptide $\mathrm{Y}$ on seabream gonadotropin releasing hormone release in vitro from preoptic-anterior hypothalamus and pituitary of red seabream, Pagrus major. Journal of Neuroendocrinology 13(5): 395-400.

Sholichah L, Subandiyah S, Satyani D. 2010. Siklus reproduksi tahunan ikan ringau, tiger fish (Datnioides quadrifasciatus) di lingkungan budidaya akuarium dan bak. In: Sudrajat A, Rachmansyah, Hanafi A, Azwar ZI, Imron, Kristanto AH, Chumaidi, Insan I (ed.). Forum Inovasi Teknologi Akuakultur 2010. Pusat Penelitian dan Pengembangan Perikanan Budidaya, BRKP-KKP. Jakarta. p 417-424.

Sokolowska-Mikolajczyk M, Gajdzinski D, Gosiewski G, Socha M. 2015. Serotonin, GnRH-A, and dopamin interaction in the kontrol of in vivo luteinizing hormon release in Prussian carp (Carassius gibelio Bloch) at the time of gonad recrudescence. Czech Journal of Animal Science, 60(2): 45-51.
Somoza GM, Yu KL, Peter RE. 1988. Serotonin stimulates gonadotropin release in female and male goldfish, Carassius auratus L. General and Comparative Endocrinology, 72(3): 374-382.

Treasurer JW, Holliday FGT. 1981. Some aspects of the reproductive biology of perch Perca fluviatilis L. A histological description of the reproductive cycle. Journal of Fish Biology, 18(3): 359-376.

Vacher C, Mananos E, Breton B, Marmignon MH, Saligaut C. 2000. Modulation of pituitary dopamine D1 or D2 receptors and secretion of both FSH and LH during the annual reproductive cycle of female rainbow trout. Journal of Neuroendocrinology, 12(12): 1219-1226.

Vacher C, Ferriere F, Marmignon M-H, Pellegrini E, Saligaut C. 2002. Dopamine D2 receptors and secretion of $\mathrm{FSH}$ and $\mathrm{LH}$ : role of sexual steroids on the pituitary of the female rainbow trout. General and Comparative Endocrinology, 127(2): 198-206.

Van der Kraak G. 2009. The GnRH system and the neuroendocrine regulation of reproduction. In: Bernier NJ, Van der Kraak G, Farrell AP, Brauner CJ (eds.). Fish Physiology volume 28: Fish Neuroendocrinology. Academic Press. Burlington. pp. 115-149.

Wahyuningsih H. 2012. Induksi buatan pada perkembangan gonad ikan Tor soro. Disertasi. Sekolah Pascasarjana Institut Pertanian Bogor. Bogor. 94 hlm.

Yu KL, Rosenblum PM, Peter RE. 1991. In vitro release of gonadotropin-releasing hormone from the brain $\mathrm{p}$-anterior hypothalamic region and pituitary of female goldfish. General and Comparative Endocrinology, 81(2): 256-267.

Yaron Z, Levavi-Sivan B. 2011. Endocrine regulation of fish reproduction. In: Farrell AP (ed.). Encyclopedia of Fish Physiology: from genome to environment. San Diego, Academic Press 2: 1500-1508. 